\section{World congress quits Southampton for Mainz}

THE University of Mainz (West Germany), rather than Southampton (England), will host the 11th World Archaeology Congress in September 1986. The executive committee of the International Union of Prehistoric Sciences (IUPPS), at an extraordinary meeting in Paris last week, took the unprecedented step of "withdrawing recognition" of the congress from the University of Southampton.

Professor John Evans, chairman of the executive committee and president of IUPPS, resigned his position during the Paris meeting, but is to stay on as an ordinary member of the executive. Professor Peter Ucko, organizer of the Southampton congress, ceased to be a member of the executive after the decision to remove the congress from Southampton and left the Paris meeting before it ended.

IUPPS's decision resolves the bitter dispute caused by the banning of South African delegates, including scientists of other nationalities who work in South Africa, from the Southampton meeting (see $\mathrm{Na}$ ture 317,$754 ; 1985$ ). The ban resulted from pressure by Southampton's city council and university teachers' and students' trades unions, although Ucko argued strongly against it.

More than 200 participants from the United States, as well as the delegations from France, West Germany, The Netherlands, Belgium, Switzerland and Spain, would have boycotted the meeting

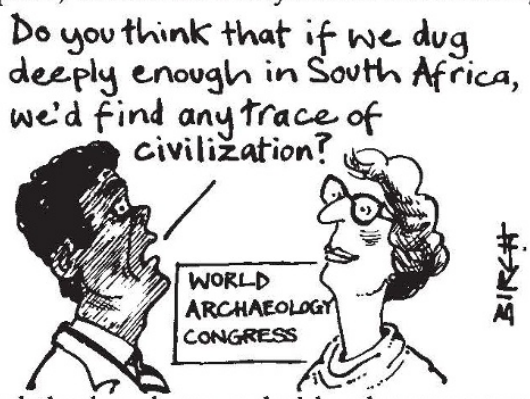

had the ban been upheld, whereas many African delegates would not have attended had the ban not been introduced. The IUPPS executive took its action because the organizing committee of the Southampton meeting had departed from IUPPS's statutes and longstanding policy to keep all its activities open to all "bona fide scholars". For more than 50 years, the 10 congresses sponsored by IUPPS have been organized on this basis and scholars have been admitted irrespective of race, nationality, religion or political convictions.

The new president of IUPPS and chairman of the executive committee is Profes- sor K. Böhner of Mainz, and Dr K Weidermann is the organizing secretary. Notice of the decision to move the congress is to be sent to the members of the permanent council of IUPPS for approval by postal vote.

Professor Phillip Tobias, a member of the council, said in Paris this week that the action "constitutes a landmark decision in the history of the struggle for the freedom of science and for the free circulation of scientists. . . . The IUPPS resolutions constitute a striking reaffirmation of the need to keep scientific intercourse and the access to knowledge free from political, racial or geographical limitations."

Maxine Clarke

\section{Searle's UK research lab closes}

G.D. SEARLE, the US drug company, is to end its pre-clinical research programme in the United Kingdom by closing its High Wycombe laboratories with the loss of $\mathbf{3 0 0}$ jobs. The decision was made largely to avoid a "duplication of effort" in company laboratories in other countries and is part of a worldwide reorganization of the company in the wake of Searle's recent merger with the giant US chemical company Monsanto. At that time, Searle said that the research enterprises of the two companies would reinforce each other.

Much of Searle's UK research effort will be absorbed by Monsanto's directly comparable biotechnology research institute in St Louis, Missouri; the rest will go to Searle laboratories in Belgium and France. Staff will be offered transfers on an "individual basis".

Searle's decision to stop its UK programme stems partly from its disillusionment with the British government's recent regulations designed to save money on National Health Service drugs prescriptions. British-owned companies get a better price for drugs than foreign companies. But a company spokesman stressed last week that Searle will spend more this year on research and development worldwide than ever before; \$160-170 million in 1986 compared with \$130-140 million in 1985 . And individual projects in universities, for example a $£ 1$ million project at thc University of Oxford, will continue. Searle is now looking for a new site in High Wycombe for its business operations - the present laboratories are considered "unsuitable" for that purpose. Maxine Clarke
Channel tunnel

\section{Rail plan gets go-ahead}

AFTER nearly two centuries of talking, Britain and France are to be linked by a tunnel under the English Channel ( $\mathrm{La}$ Manche, the "sleeve", to the French). A historic moment? Not to judge by the French media, which have taken very little interest in the prospect of getting from Paris to London in three and a half hours rather than five.

This is understandable. Through the tunnel, Britain sees the whole of Europe: France sees only Britain. And what do the French think of Britain? In a recent poll by a French science magazine, readers were asked with which country they would like to see French industry and scientists cooperating in high technology. Nearly 30 per cent said West Germany. Only 1 (yes, 1) per cent said Britain.

But, notwithstanding popular French indifference, Prime Minister Margaret Thatcher and President François Mitterrand announced on Monday that construction can now begin of a twin-bore rail tunnel, though which trains will carry freight direct and cars piggy-back. The rail tunnel should be open by 1993 . This looks like defeat for the "road" lobby, Mrs Thatcher included, although the winning consortium, the Channel Tunnel Group (CTG), will be asked to prepare plans for a twin road tunnel to be built within fifteen years - if it appears economic.

The decision has not pleased those placed either side of the tunnel. The mayor of Calais, the principal French ferry port, has said that within a few years of the opening of the tunnel Calais would become "a ghost town". That might be true, and the same for Dover, if the rail tunnel provides transit at costs much lower than the ferries, as predicted by CTG's chairman, Sir Nicholas Henderson. A spokesman for the now-defunct "Euroroute" bridge scheme, however, claims that drilling problems and heating and ventilation of a tunnel will force up costs far beyond those now predicted.

A more optimistic scenario, however, has it that the "chunnel" will indeed reduce transit costs, and thus encourage new industries to set up near the tunnel entrances. However, the zone south of the tunnel (in north-east France) may well prove more attractive than that north of it (in Kent and Sussex), as the former will also provide a crossroads for traffic moving east and west across Europe.

French rail interests are also keen on the prospect of running the advanced French high-speed train, TGV (Train Grand Vitesse) to London. In many ways, it seems, Monday's decision looks like a French success.

Robert Walgate 